\title{
Performances de gênero e gêneros em performance: reflexões sobre a arte e os corpos de Michel Journiac
}

\author{
Gender performances and genders in performance: \\ reflections on the art and the bodies of Michel Journiac
}

\section{Performances de género y género en performance: reflexiones acerca del arte y de los cuerpos de Michel Journiac}

\author{
iD) Vitor Grunvald \\ Universidade Federal do Rio Grande do Sul, Porto Alegre, Rio Grande do Sul, Brasil \\ vgrunvald@gmail.com
}

\begin{abstract}
Resumo: O artigo se apropria tanto de discussões antropológicas quanto das provenientes de outros campos disciplinares, como história da arte e filosofia, para refletir sobre políticas e poéticas relativas a performances de gênero, tendo como material de análise algumas obras dos artistas Marcel Duchamp e, especialmente, Michel Journiac. Para tanto, primeiramente, retomo uma série de elaborações teóricas sobre vestuário e roupa em sua relação com o corpo. Posteriormente, discuto questões relacionadas a práticas de travestimento e experiências que tencionam problemas de gênero no campo artístico. Por fim, analiso as inextricáveis relações entre roupa, corpo e possibilidades de vida, e transição/transmutação no sentido de propor políticas e poéticas que não operam pelas determinações das ciências psi, em geral acionadas para erigir conceituações sobre prática de travestimento.
\end{abstract}

Palavras-chave: Performance. Arte corporal. Políticas. Poéticas. Gênero. 
Abstract: The article appropriates both anthropological discussions and those coming from other disciplinary fields such as art history and philosophy to reflect on politics and poetics related to gender performances, having as analysis material some works by artists Marcel Duchamp and, especially, Michel Journiac. To do so, I first resume a series of theoretical elaborations on costume and clothing in relation to the body. Subsequently, I discuss issues related to practices of cross-dressing and to experiences that address gender issues in the artistic field. Finally, I analyze inextricable relations between clothes, body and possibilities of life and transition/transmutation in order to propose politics and poetics that do not operate by the determinations of the psi sciences, generally triggered to erect concepts about the practice of cross-dressing.

Keywords: Performance. Body art. Politics. Poetics. Gender.

Resumén: El artículo se apropia de las discusiones antropológicas y de otros campos disciplinarios como la historia del arte y la filosofía para reflexionar sobre políticas y poéticas relacionadas con las performances de género, utilizando como material para el análisis algunas obras de los artistas Marcel Duchampy, especialmente, Michel Journiac. Para hacerlo, primero, vuelvo a una serie de elaboraciones teóricas sobre la ropa y la ropa en relación con el cuerpo. Posteriormente, discuto cuestiones relacionadas con prácticas y experiencias de travestimiento que abordan cuestiones de género en el campo artístico. Finalmente, analizo las relaciones inextricables entre la ropa, el cuerpo y las posibilidades de la vida y la transición / transmutación en el sentido de proponer políticas y poéticas que no operan por las determinaciones de las ciencias psi, que generalmente se utilizan para construir conceptos sobre la práctica de travestir-se.

Palabras clave: Performance. Arte corporal. Políticas. Poéticas. Género.

Data de recebimento: 14/03/2020

Data de aprovação: 11/12/2020 
Performances de gênero e gêneros em performance: reflexões sobre a arte e os corpos... Vitor Grunvald

O corpo é primeiro, ele aparece com o sangue e as roupas Michel Journiac, L'objet du corps et le corps de l'objet, L'Humidité, 1973

Em seu extenso livro A fotografia: entre documento e arte contemporânea, André Rouillé (2009[2005]) levanta a questão de como o travestimento é utilizado por alguns artistas para subverter expectativas sociais, através da inversão das prescrições de gênero, construídas a partir da ideia de uma diferença sexual' ${ }^{1}$.

Em outros momentos (GRUNVALD, 2015, 2016), tentei expor como a performance de gênero, levada a cabo pelo agenciamento artístico de algumas obras de Marcel Duchamp, acaba por suscitar questões, plantear problemas e provocar uma espécie de curto-circuito, cuja fagulha é a prática do travestimento. Contudo, creio ser preciso ir além da análise meramente formalista, que se preocupa apenas com as relações internas à obra, e focar também na importância de situar essas obras e artistas no emaranhado de relações sociais que, de alguma maneira, constituem a eles e suas preocupações, e que, portanto, participam de seus agenciamentos artísticos.

Não podemos prescindir de ambas as abordagens: ainda que as obras, como índices da agência distribuída desses artistas - segundo a sugestão de Alfred Gell (1998) - estejam sempre remetidas às relações sociais, que não apenas dão sentido a esses agenciamentos, mas os produzem. A maneira pela qual os artistas realizam essas obras é igualmente calcada no conjunto de relações (formais) intrínsecas tanto ao seu trabalho artístico como um todo, quanto à tradição artística com a qual dialogam.

Nesse sentido, uma análise como a que realizei deve estar conjugada - pelo menos dentro de uma perspectiva eminentemente antropológica, aqui entendida como aquela que enfoca as relações sociais mobilizadas - com questões relativas à eficácia dos objetos de arte.

1 Para elaborações sobre a questão da diferença sexual na antropologia, bem como sua relação com gênero como sua contrapartida sócio-cultural, cf. Grunvald, 2009. 
Performances de gênero e gêneros em performance: reflexões sobre a arte e os corpos... Vitor Grunvald

Nicholas Thomas, no prefácio ao livro de Alfred Gell, chama atenção para esse fato quando afirma que "objetos de arte mediam uma tecnologia para alcançar certos fins, notadamente para enredar pacientes em relações e intencionalidades solicitadas ou prescritas por agentes". No entanto, segue o raciocínio, não devemos tomar isso como "uma abordagem redutiva da arte, aquela que toma os objetos essencialmente como veículos de estratégias", já que "é importante enfatizar que a complexidade formal e, certamente, a virtuosidade técnica exibidas pelos objetos de arte não são incidentais ao seu argumento, mas absolutamente centrais a ele" (THOMAS, 1998, p. x, tradução minha)2.

A questão que gostaria de trazer, antes de iniciar a análise de alguns aspectos relativos às relações sociais mobilizadas pelo contexto no qual Duchamp está inserido, é trabalhada também por Gell (1993) no livro Wrapping in images. Para abordar a tatuagem na Polinésia, ele adota uma inspiração explicitamente foucaultiana na qual os corpos estão diretamente envolvidos em um campo político composto por relações de poder que investem e marcam estes corpos pela realização de um tipo particular de sujeição.

Gell parte da ideia de que existe, na Polinésia, uma proporcionalidade inversa entre as artes corporais (principalmente, a tatuagem) e a centralização política. Em outras palavras, na Polinésia, para usar uma frase simplificada: quanto menos Estado, mais tatuagem. A existência de uma vívida prática de artes corporais é sempre acompanhada de sistemas sociais mais abertos (competitivos), ao passo que sistemas sociais mais fechados (estratificados) parecem coibir a emergência de tais práticas. Gell chama atenção para o fato de que

é importante reconhecer que o significado da tatuagem nos sistemas de tatuagem local não é nunca autônomo; os esquemas técnicos não são lidos isoladamente, mas em conjunção com outros esquemas técnicos - outras mutilações, outros tratamentos de invólucro corporal, incluindo as roupas, outras formas de arte e formas de produção de prestígio, etc. (GELL, 1993, p. 9).

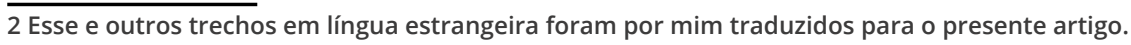


Performances de gênero e gêneros em performance: reflexões sobre a arte e os corpos... Vitor Grunvald

Cabe pontuar também a retomada que faz das teorias de Cesare Lombroso, que falam explicitamente da tatuagem como uma predisposição quase biológica de indivíduos propensos à criminalidade. Adolf Loos, por sua vez, postula uma sobrecodificação (ou um nexus universal, como chama Gell) entre primitivismo/ criminalidade/ornamentabilidade e civilização/constrangimento/ funcionalidade.

Nesse sentido, as modernas sociedades ocidentais parecem ter uma posição exatamente inversa às das sociedades ditas tribais, na medida em que estas últimas veem as decorações e os adornos como marcas de civilização (RUBIN, 1988). A distinção de percepção vai além dos sinais invertidos, já que existem maneiras distintas de perceber estas marcas, para além de sua valoração como positivas ou negativas:

enquanto em sociedades não-hierárquicas as marcas corporais revelam um eu imanente que é interior ao corpo e que pode ser feito aparecer na pele, em sociedades hierárquicas as marcas corporais são marcas que se impõem de fora e significam a supressão do corpo desvalorizado e do que ele representa (GELL, 1993, p. 26).

A ideia de que ornamentos e decorações são marcas de construção do próprio corpo a partir de um processo, tanto de sujeição quanto de subjetivação ${ }^{3}$, é fundamental para entendermos as estratégias artísticas de Marcel Duchamp, sem levar em conta a maneira pela qual o artista maneja prescrições de gênero na (de) composição de uma corporalidade, a partir da utilização diferencial de ornamentos e adereços.

Essa manipulação atenta novamente para um tipo específico de consumo. De fato, tanto no âmbito das informações provenientes do trabalho de campo que realizei (GRUNVALD, 2016) quanto do agenciamento artístico que estou analisando, a partir de

3 Gell (1993, p. 4), novamente a partir de Foucault, considera a formação de sujeitos tanto como sujeição quanto como subjetivação - ainda que não discuta a subjetivação como uma possibilidade de, em determinadas situações sociais, escapar ou subverter a sujeição social. 
Performances de gênero e gêneros em performance: reflexões sobre a arte e os corpos... Vitor Grunvald

Duchamp e Journiac, o consumo se mostra como fundamental na delimitação das diversas estratégias empreendidas pelos sujeitos. ${ }^{4}$ Note-se que os próprios ready-mades de Duchamp não existiriam sem o mercado de bens de consumo que eles parodiam.

Significativo para os fins deste artigo é o consumo de roupas e acessórios, através dos quais se constrói uma determinada corporalidade generificada, que se conjuga com performances de gênero específicas. $E$, portanto, acho necessário empreender uma discussão sobre o tipo de abordagem que utilizo em relação ao uso desses elementos.

\section{As roupas como (objetificações de) relações sociais}

6

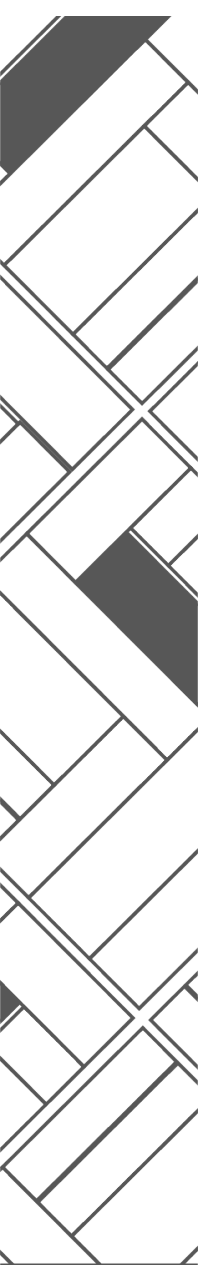

Peter Gow, no texto Clothing as acculturation in Peruvian Amazonia, lembra sua reação estética à aparência visual dos indígenas do rio Bajo Urubamba quando teve o primeiro contato com eles. Os Piro não usavam roupas consideradas tradicionais, mas aquilo que, naquela região, costuma-se chamar "roupa de branco". Qual o significado disso? Estariam os Piro virando brancos? Eles esperam, com isso, passar por brancos? - pergunta-se Gow. Não! Responde.

O valor fundamental para os Piro é gwashata, que significa viver bem, viver em comunidades harmoniosas cheias de parentes que compartilham comida e se ajudam mutuamente. ${ }^{5}$ Em contraste, os brancos são mshinikatu, isto é, "indiferentes, sem amor, estúpidos, ignorantes" e por isso chamar alguém de kajitutachri ("alguém que habitualmente age como branco") é sempre um insulto. Mas dada essa conotação negativa atribuída ao branco e suas atitudes ou modos de vida, por que então usar roupas de brancos?

\footnotetext{
4 Para uma discussão antropológica sobre as relações entre consumo e subjetividade, com ênfase nas questões de gênero e sexualidade, cf. FRANÇA, 2012.

5 Viver bem, gwashata, é “a manisfestação coletiva do nshinikanchi, 'memória, amor, cuidado, atenção', de cada co-residente. O nshinikanchi de uma pessoa se desenvolve na retribuição dos atos de cuidado durante a infância: o cuidado de uma criança com os outros é tornado evidente através de presentes de comida, atenção e interação bem-humorada" (GOW, 2007, p. 58).
} 
Performances de gênero e gêneros em performance: reflexões sobre a arte e os corpos... Vitor Grunvald

Gow aponta a associação das roupas de branco com o que poderíamos chamar de "roupas tradicionais", mas que os Piro chamariam, mais propriamente, de "roupas dos antigos". "Os Piro, atualmente, temem suas 'roupas tradicionais', pois essas roupas, em seus olhos, os fazem parecer onças" (GOW, 2007, p. 59). Assim sendo, esse tipo de vestimenta - que Gow associa a um afeto-onça - é adequada para lidar com relações potencialmente conflituosas ou em momentos rituais, mas não em situações cotidianas da vida diária. ${ }^{6}$

Um mito contado a Gow narra as desventuras do filho de uma mulher sem marido que, para sustentar a mãe, ia para a floresta e, tirando sua roupa (cushma), transformava-se em onça com vistas a conseguir carne de caça. Ao terminar a caça, colocava novamente sua cushma e voltava a ser humano, levando a carne para sua mãe. Em contraste com o uso e os significados em relação às suas roupas tradicionais, esse mito permite ao autor entrever o caráter perspectivista da cosmologia piro, já que, “[d]e fato, a 'onça-homem' trata a vida diária da maneira que os Piro tratam os eventos rituais: a 'onça-homem' usa as roupas piro, um afeto-humano, para promover relações diárias com sua mãe da mesma maneira como os Piro usam um afeto-onça para promover suas relações rituais entre eles" (GOW, 2007, p. 60).

Com efeito, Gow pontua que um elemento chave a ser considerado no entendimento da transformação da relação entre homens brancos e índios piro é o acesso às roupas de branco. “Um tema constante nos relatos das primeiras relações de exploração era o quanto as pessoas [Piro] tinham que sofrer para conseguir essas roupas [de brancos]" (GOW, 2007, p. 63). A aquisição de roupas de branco é, continua o autor, "uma manifestação muito visível do estado das relações piro com os homens brancos. Como vimos, a roupa importa para os Piro e é, certamente, seu protótipo do objeto possuído" (GOW, 2007, p. 64).

6 As ocasiões, por excelência, quando os Piro usam "roupas tradicionais", ocorrem durante os rituais de iniciação das meninas, kigimawlo. "Esse conglomerado de 'todos os Piro ao longo do rio' promove a copresença de pessoas com um histórico de más relações, pessoas conectadas não por seu 'cuidado' uns com os outros, mas pela sua 'indiferença'” (GOW, 2007, p. 59). 
Performances de gênero e gêneros em performance: reflexões sobre a arte e os corpos... Vitor Grunvald

Nesse sentido, as roupas não devem apenas ser compreendidas do ponto de vista semiológico ou axiológico. Elas não são somente veículos de significado ou portadoras de valores, mas concretizam e objetificam relações sociais - uma perspectiva muito próxima, portanto, da utilizada por Gell em suas reflexões sobre objetos de arte.

Gell propõe que se estude objetos de arte antropologicamente, ou seja, sob a perspectiva das relações sociais. Do ponto de vista da antropologia social, qualquer coisa pode ser pensada como objeto de arte, incluindo-se aí pessoas vivas. Assim, o autor define a teoria antropológica da arte como "as relações sociais na vizinhança de objetos que mediam agência social" e que se fundem, portanto, com as problemáticas de uma antropologia social das pessoas e seus corpos (GELL, 1998, p. 7).

Segundo Els Lagrou (2007), a proposta de Gell de aproximar artefatos e pessoas parece menos estranha ao esforço teórico da antropologia se pensarmos que esta se debruça, desde seus primórdios, sobre discussões acerca do animismo - a atribuição de sensibilidade a coisas inanimadas, plantas e animais etc. A teoria da agência de Gell dá ênfase ao que os objetos fazem, como agem e não apenas ao que significam, assertiva que, considerada isoladamente, estaria mais alinhada a uma abordagem simbólica dos estudos antropológicos da arte.

Minha sugestão é que a relação entre pessoas e adereços, operada a partir da prática de vestir-se com roupas do gênero associado ao sexo oposto, também não pode ser pensada como se remetendo apenas a uma significação, mas à construção de uma imagem-corpo específica. É uma ontologia e não uma semiótica que é visada por esse agenciamento. Corpos biologicamente masculinos transformados em femininos e vice-versa. Corporalidades que buscam instaurar sua condição de existência num lugar que não seja nem masculino nem feminino.

Em todos os casos, a questão é construir uma corporalidade e, muitas vezes, uma subjetividade que a habite. Nesse sentido, 
Performances de gênero e gêneros em performance: reflexões sobre a arte e os corpos... Vitor Grunvald

parece haver extrema penetração entre as discussões desenvolvidas a partir de uma antropologia do vestuário, a antropologia da arte de Gell e o estudo de práticas de travestimento. A ideia de atribuir agência a objetos perpassa igualmente a perspectiva defendida por Bruno Latour (1994[1991], 2005), para o qual devemos construir um tipo de teoria antropológica capaz de pensar tanto humanos quanto não-humanos e sua relação.

Não estou, certa e inocentemente, interessado em propor que pessoas que se travestem e ameríndios lidem com estas questões da mesma maneira. Enquanto a consubstancialidade entre corpo e roupa é, parece-me, vista como real ou, mais propriamente, literal no caso dos ameríndios; para nós, ocidentais, - e, portanto, para as pessoas que se travestem, com as quais realizei minha pesquisa de doutorado e que inspiraram ou, antes, exigiram essa a busca conceitual que aqui realizo, ainda que não estejam presentes neste artigo -, essa consubstancialidade só figura socialmente como metafórica. Já que isso nunca ocorreria de maneira plena, senão a partir do polo privilegiado de determinação ontológica, isto é, do corpo biológico tido como natural. ${ }^{7}$

Assim, argumentam alguns, não é possível considerar que uma pessoa designada como homem, que se reivindique como mulher e construa seu corpo através de performances e adereços femininos, seja realmente uma mulher, visto que, naturalmente, ou seja, biologicamente, possui corpo de homem. Esse é um dos sentidos pelos quais é possível afirmar que a prática de travestimento é, em nossa sociedade, considerada contra-hegemônica ou socialmente subversiva - ainda que, como discutirei, seja perigoso afirmar que assim o é em todos os casos e situações.

De fato, a verificação ou atenção ao caráter contra-hegemônico do travestimento, a partir de práticas de pensamento marcadas pelo dimorfismo sexual, é importante para que não naturalizemos a relação entre gênero e corpo sexuado, isto é, para a percepção de que o gênero é construído performativamente. Ao perceber a

7 Agradeço a Maria Filomena Gregori pelas observações que deram origem a esse cuidado metodológico na comparação entre concepções de gênero melanésias e euroamericanas. 
Performances de gênero e gêneros em performance: reflexões sobre a arte e os corpos... Vitor Grunvald

transgressão da performance de drag queens, argumenta Butler (2001[1990]), reconhecemos a arbitrariedade ou, antes, a contingência (porque não se trata de dizer que é inteiramente arbitrário, já que informadas por normas socioculturais) das categorias homens e mulheres, de masculino e feminino. Se toda e qualquer feminilidade é construída performaticamente, "entre uma mulher e uma drag queen, a diferença é o comprimento do salto", como fala, não sem ironia, Marie-Hélène/Sam Bourcier (2015, p. 12).

Mas devemos ir adiante. Não importa tanto o que uma coisa é, mas como ela funciona. "A questão aqui não é desafiar o conhecimento positivo [GREGOR; TUZIN, 2001], mas saber em relação a que devemos ser positivos." (STRATHERN, 2001, p. 224). O importante não é dizer que gênero é construído, mas entender de que forma isso que chamamos de gênero opera em cada caso concreto. Que relação (da relação) entre masculino e feminino é operada?

\section{0}

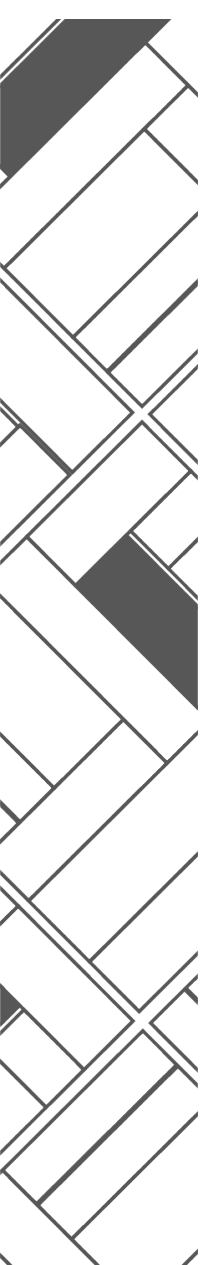

\section{Travestimentos de gênero, raça e classe}

Em seu livro The language of fashion, Barthes inicia o capítulo Dandyism and fashion, pontuando que

por séculos havia tantos itens de roupa quanto classes sociais. Toda condição social tinha sua vestimenta e não havia constrangimento em fazer de uma roupa um verdadeiro signo, já que a distância entre as classes era considerada natural. Assim, por um lado, a indumentária estava sujeita a um código inteiramente convencional, mas, por outro lado, esse código estava referido a uma ordem natural ou, melhor ainda, a uma ordem divina. Mudar as roupas era mudar tanto de ser quanto de classe social, pois uma era parte integrante da outra (BARTHES, 2005[1998], p. 65). 
Performances de gênero e gêneros em performance: reflexões sobre a arte e os corpos... Vitor Grunvald

Anne Mcclintock, a partir de fotografias e relatos que contam a história de Hannah Cullwick e Arthur Munby na Inglaterra do século XIX, aponta para o uso diferenciado que Hannah fazia dos ornamentos e adereços para promover um travestimento ${ }^{8}$ não apenas de gênero, mas também de raça e classe. Em relação ao casal, McClintock afirma que

[o]s roteiros de sua vida de fantasia eram fundamentalmente uma transgressão teatral das iconografias vitorianas de domesticidade e raça, e seus rituais fetichistas tomavam forma em torno da afinidade crucial, mas oculta, entre o trabalho da mulher e o império. (MCCLINTOCK, 2010[1995], p. 207).

Nas diversas fotografias apresentadas pela autora, Cullwick aparece negra, masculina e sentada no chão como um escravo; sentada numa cadeira com vestido e postura tipicamente aristocráticas; "disfarçada de dama", mas, também, como trabalhadora rural e travestida de homem com terno e gravata.

Esse fetichismo que era tanto de gênero quanto de classe e raça, valia-se da iconografia para construir, através de determinadas performances, territórios existenciais alternativos à posição cotidiana de Cullwick e, nesse sentido, "era uma tentativa - ambígua, contraditória e nem sempre bem-sucedida - de negociar os limites de [seu] poder" (MCCLINTOCK, 2010[1995], p. 208). O próprio travestimento permite a Cullwick explorar a tensão entre as limitações sociais e sua atuação social.

Em seus rituais de organização teatral do risco social, Cullwick e Munby se valiam do fetichismo encarnado em roupas e objetos como signos visíveis de marcação de posição social. O fetichismo da mercadoria, portanto, aparece como central e mais uma vez aponta para os ornamentos e adereços como elementos que objetificam relações sociais, tal qual falou Peter Gow em relação às roupas Piro.

8 De fato, McClintock (2010[1995]) utiliza a palavra travestismo que aqui substituo por travestimento (exceto no caso de citações ipsis litteris), já que não se está discutindo a questão do travestismo como patologia cientificamente enquadrada pela psiquiatria. 
Performances de gênero e gêneros em performance: reflexões sobre a arte e os corpos... Vitor Grunvald

Contra uma leitura meramente psicológica, McClintock alerta que o travestimento "não é só um fetiche pessoal, ele é também um fenômeno histórico" (MCCLINTOCK, 2010[1995], p. 259). Dessa forma, "leis suntuárias procuraram regular as fronteiras sociais regulando a legibilidade social da roupa". Porém, é importante observar o paradoxo interno a essas mesmas leis: "o fato de que a classe e a posição são legíveis pelo vestir, ou não vestir, 'panos de ouro, seda ou púrpura' revela a natureza inventada da distinção social, tornando visíveis tanto as origens quanto a legitimidade de posição e poder" (MCCLINTOCK, 2010[1995], p. 260).

Cesare Lombroso - que, como vimos, é acionado por Gell a partir da afinidade que postula entre ornamentação e criminalidade - planteia a nascente criminologia como prática de medicina legal na qual, para usar as palavras de Jorge Leite Jr., "em uma versão laica, racional e 'científica', a dita desarmonia física ou mesmo a 'feiúra' continuam sendo vistas como um sinal de perigo, não mais pela possibilidade de desordem cósmico-espiritual, mas pelo caos político-social que podem instaurar" (LEITE JR., 2011, p. 80). Nesse mesmo período da segunda metade do século XIX, Kraft-Ebing produz um amplo inventário de patologias neuropsicológicas das funções sexuais, inclusive do fetichismo, sadismo e masoquismo elementos presentes na exploração que McClintock faz da história de Cullwick e Munby.

$\mathrm{Se}$, no caso de Cullwick, o travestimento sinaliza sua "recusa aos papéis sociais limitados que lhe foram destinados" (MCCLINTOCK, 2010[1995], p. 264), no caso de Duchamp, contudo, essa arbitrariedade era utilizada no sentido de desestabilizar, não as limitações de seu papel social, mas uma encarnação específica e pretensamente inequívoca de masculinidade e feminilidade, apontando para suas outras (de)composições e, portanto, para a ideia de ambiguidade sexual.

Jorge Leite Jr., em seu estudo sobre a invenção das categorias de travesti e transexual no discurso científico, insiste que 
Performances de gênero e gêneros em performance: reflexões sobre a arte e os corpos... Vitor Grunvald

\begin{abstract}
não podemos esquecer que para grande parte da ciência predominante neste período - e para a cultura popular também - não existe a separação entre sexo (biologia) e gênero (cultura), sendo os 'verdadeiros' homens os 'masculinos', e mulheres, as 'femininas'. Independente do que ser masculino ou feminino possa significar para o período, o importante é que fossem representados e atualizados em conformidade com os sexos considerados correspondentes: homens com masculinidade e mulheres com feminilidade, sendo qualquer perturbação desta equação e linearidade um 'desvio' ou 'perversão' (LEITE JR., 2011, p. 107).
\end{abstract}

Em trabalhos anteriores (GRUNVALD, 2015, 2019), sugeri que, ao travestir-se como Rrose Sélavy através tanto de uma performance de gênero quanto de uma iconografia tidas como femininas, Duchamp desestabiliza relações conceituais e político-sociais que conferem não apenas inteligibilidade, mas legitimidade aos corpos no regime de verdade do sexo, consolidado no século XIX e bastante difundido na primeira metade do século $X X$, inclusive com o avanço das ciências psi, especialmente, psiquiatria e psicologia (LEITE JR., 2011, p. 115). ${ }^{9}$

A interpenetração e indissociabilidade entre as ideias de corpo e adereços, ainda que de forma distinta, é, a partir dos exemplos que vimos, enfatizada no uso diferencial das roupas operado pelo travestimento tanto de Cullwick quanto de Duchamp. Mas é Michel Journiac e sua arte corporal que levam o argumento às suas últimas consequências, apontando, de forma pungente, para as inextricáveis relações entre roupa, corpo e possibilidades de vida e transição/transmutação.

9 A citação do livro de Schreber feita por Leite Jr. é a seguinte: "quanto às peças do vestuário (a "armadura", como diz a expressão da língua fundamental), a diferenciação entre o masculino e o feminino era, quanto ao essencial, evidente por si mesma; as botas pareciam ser um símbolo particularmente característico da masculinidade. 'Tirar as botas' era por isso uma expressão que queria dizer aproximadamente a mesma coisa que emasculação" (apud LEITE JR., 2011, p. 115). Cf. adicionalmente, o fetiche de Cullwick por botinas (MCCLINTOCK, 2010[1995], p. 247-58). 
Performances de gênero e gêneros em performance: reflexões sobre a arte e os corpos... Vitor Grunvald

\section{Michel, vampiro, e o sangue ${ }^{10}$}

Michel Journiac é um vampiro. Ao menos a imagem do vampiro é prolífica para pensar suas práticas e proposições artísticas. Num texto de 1971, publicado na revista arTitudes, o vampiro aparece como uma figura catalizadora. Por um lado, ele é "a expressão simbólica de tudo aquilo que, na sexualidade, é repelido pela moral social"; por outro lado, a força do vampiro está na "efetividade de seu ritual, cuja dialética opõe uma sexualidade destituída de sentimentalismo e reduzida ao consumo do outro pelo sangue a uma religião limitada ao formalismo (cruz, exorcismo...), de fato, a uma sociedade fundamentalmente burguesa" (JOURNIAC, 2013, p. 70).

A relação inextricável com o poder corrosivo de gêneros e sexualidades dissidentes ${ }^{11}$ não é invenção de Journiac. Em O Segundo Sexo, Simone de Beauvoir também recorre à imagem do vampiro para falar sobre algumas concepções socioculturais relativas à mulher. "A mulher é vampiro, mutiladora, come e bebe e seu sexo alimenta-se gulosamente do sexo masculino" (BEAUVOIR, 1970[1949], p. 212).

Jack Halberstam, em seu livro sobre o horror gótico e a tecnologia dos monstros, analisa como tanto na retórica do vampirismo quanto nos discursos sobre raça e etnicidade, o sangue é um signo sobredeterminado que "significa raça tanto quanto sexo, gênero e classe e ter sangue nas mãos é estar implicado no borramento de fronteiras essenciais de identidade" (HALBERSTAM, 1995, p. 77).

Journiac, como um vampiro, foi sempre fascinado por sangue. Desde suas primeiras pinturas na década de 1960 a suas esculturas e instalações mais tarde, esse líquido vital, essência que dá vida, foi um elemento onipresente. O vampiro corporifica a ideia

\footnotetext{
10 A pesquisa sobre a obra de Michel Journiac foi realizada quando estive como Graduate Research Trainee no Departamento de História da Arte da McGill University (Montréal/CA) sob orientação da crítica, curadora e historiadora da arte Amelia Jones. Esta estadia, bem como o trabalho de pesquisa de arquivo sobre arte corporal na França na década de 1970 que realizei na Bibliothèque Kandinsky do Centre national d'art et de culture Georges-Pompidou em Paris, foi possibilitado pela concessão de uma Bolsa de Estágio de Pesquisa no Exterior (BEPE n 2013/21735-9) da Fundação de Amparo à Pesquisa do Estado de São Paulo (FAPESP).

11 Utilizo o adjetivo dissidente(s), após Díaz-Benítez e Fígari (2009), para me referir a sexualidades e gêneros que bem poderiam ser também chamados de disparatados (MISKOLCI e SIMÕES, 2007).
} 
Performances de gênero e gêneros em performance: reflexões sobre a arte e os corpos... Vitor Grunvald

de que a vida flui e, caso não se tenha cuidado, pode escapar do corpo. Ele também expressa sua estabilidade precária e sugere que as fronteiras de identidade, das quais fala Halberstam, são também fronteiras que marcam os limites da vida e da morte.

Seguindo a tradição vampiresca, sempre propôs que a relação entre morte e vida - incluindo sua separação absoluta - é problemática. Em seus trabalhos, essa relação, devido à sua instabilidade, é dobrada recursivamente e dá lugar a uma indagação dentro da própria vida, sobre os modos de existência e possibilidades de transformação.

No primeiro volume da revista arTitudes, publicada em outubro de 1971, Journiac faz explicitamente o que chama de "interrogação sobre o corpo", um corpo que é exposto como "origem do perigo para a sociedade e para o indivíduo, ponto de encontro para outros corpos e ostentação da armadilha social" (JOURNIAC, 2013, p. 75). Com efeito, mesmo antes dos seus trabalhos de 1970, que são abertamente caracterizados como art corporel, o corpo já era uma preocupação central do artista.

Em seus óleos sobre tela dos anos 1960, encontramos não apenas ressurreição, mas também sacrifício e processos que são eminentemente corporais. De fato, as figuras abstratas de suas pinturas parecem ter apenas sangue e carne para oferecer ao olhar do espectador. No mesmo ano em que pintou Sacrifício, ele também pintou De corpo distanciado onde, naquilo que é mais ou menos reconhecível como um corpo (tudo pode ser um corpo...), vemos linhas e curvas que podem ser percebidas como seios. A figura, no entanto, não é inequivocamente feminina. Carne e sangue extrapolam os limites do quadril pelo meio das pernas, espaIham-se para o fora-da-tela e parecem indicar a presença de um órgão sexual masculino. Já estava aí a travesti?

O entrelaçamento dessa massa amorfa de sangue e carne com um símbolo gráfico grande e vermelho, conformando um signo de sangue, aponta para a importância de elementos corporificados. Sim, o corpo é um suporte para Journiac. Mas apenas se conside- 
Performances de gênero e gêneros em performance: reflexões sobre a arte e os corpos... Vitor Grunvald

rarmos que não existe um Eu original do qual ele é suporte - ou, pelo menos, não existe apenas um. Após os primeiros experimentos iconográficos, a obra de Journiac substitui o suporte da pintura pelo corpo como suporte, refutando a primeira como meio único de produzir arte.

\section{Em direção à arte corporal}

Não é que Journiac tenha sempre impugnado a pintura. Na carta que escreveu ao seu pai, em junho de 1962, assumindo sua homossexualidade e dizendo que estava deixando para trás "qualquer orientação sacerdotal", ele também afirmou ter descoberto a pintura como havia feito antes com a literatura. ${ }^{12}$

No entanto, como disse um de seus alunos, "essa prática [a pintura] era muito ligada a um determinado meio social que usou a arte como mais-valia e não como vivência artística" (apud JOURNIAC, 2013, p. 11). Journiac fala sobre Dadaísmo em muitos de seus escritos e, tal como Duchamp, cedo rejeitou que a arte se tratava sobretudo do retiniano. ${ }^{13}$

Missa para um corpo, uma performance que realizou na Galeria Daniel Templon no dia 6 de novembro de 1969, com a assistência dos críticos de arte Pierre Restany e Catherine Millet, foi certamente um ponto de inflexão. Nesta ação, Journiac realiza uma missa em latim, vestido (travestido?) como um padre. Ao fim da Eucaristia, no lugar da Hóstia, ele oferece à audiência fatias de boudin, uma espécie de linguiça francesa, feita com seu próprio sangue. A drenagem do sangue ocorrida anteriormente foi fotografada e a receita da linguiça de sangue humano foi disponibilizada ao público. Ambas faziam parte da obra.

\footnotetext{
12 “Como eu descobri a literatura [...] eu encontrei a pintura. O acaso de uma exposição me fez encontrar Rouault, e ele me mostrou como a arte pode transformar a feiúra e o vício. Não havia beleza natural que devesse ser reproduzida, nem beleza ideal a ser alcançada, havia simplesmente o artista e o mundo, e a obra de arte era o resultado de seu confronto, a introdução de uma significação em um mundo que era em si mesmo desprovido dela [...] Tudo, através da pintura, podia adquirir um sentido, virar obra de arte. A pintura me confirmou aquilo que Racine, Villon e Baudelaire me haviam feito descobrir. A arte apareceu como um meio de salvação, como a própria salvação, a única possível." (JOURNIAC, 2013, p. 20-1).

13 Duchamp e seu paradigma retiniano foram, de fato, influências explícitas no trabalho de Journiac.
} 
Performances de gênero e gêneros em performance: reflexões sobre a arte e os corpos... Vitor Grunvald

Ao falar sobre esta performance, Sarah Wilson pontua que "o desafio era nada menos do que a doutrina da transubstanciação. Cristo feito homem, pelo sangue de Journiac, transforma-se em homem feito Cristo" (WIILSON, 2000, p. 164). Ressurreição? De novo os limites da vida e da morte através da imaginação e mediação corporal.

No mesmo ano, com Armadilha para um voyeur, Journiac colocou um homem nu dentro de uma gaiola feita com tubos de neon numa exposição na Galeria Martin Malburet. Como as barras eram luzes, o público não conseguia reconhecer imediatamente que ali estava um homem nu até que chegasse perto da gaiola. Podia o homem nu ver de antemão o público que o espiava? Não importa. O olhar era assim revertido numa situação de voyeurismo recíproca e eroticamente carregada. Ali, fazendo da audiência objeto do olhar do qual antes era a única detentora, os trabalhos de Journiac eram, de fato, armadilhas.

Se levarmos em conta que, tal como argumenta Schechner em relação à dança das renas dos yaquis do Arizona, "[a] força da performance está na relação muito específica entre os performers e aqueles-para-quem-a-performance-existe" (SCHECHNER, 1985, p. 215), Armadilha para um voyeur parece buscar a produção de uma autoconsciência em relação aos mecanismos sociais e psicológicos através dos quais, tanto a performance quanto a apreciação artística, são conduzidas.

Nesta obra-performance, aquele-para-quem-a-performance-existe é o público que frequenta o circuito artístico. Mas a imagem-vista-que-também-vê-o-público é um homem apresentado como parte de um objeto de arte que é, ao mesmo tempo, ocultado e oferecido ao público. Journiac não estaria insistindo, como faz também Alfred Gell (1998), que obras de arte são índices de complexas relações de intencionalidade?

Estão já aí grandes inquietações que a arte corporal e a performance viriam instalar no campo artístico a partir da década de 1970. Journiac joga exatamente com esses paradoxos e com a 
Performances de gênero e gêneros em performance: reflexões sobre a arte e os corpos... Vitor Grunvald

possibilidade de criá-los e, dessa maneira, criticar separações que consideramos bastante resolvidas.

Nesse momento, as assim chamadas vanguardas artísticas americanas não tinham passado desapercebidas na França. Michael e Ileana Sonnabend haviam aberto a Galeria Sonnabend em Paris em 1962. A arte americana estava encontrando seu caminho na França, ainda que não sem resistência. Com efeito, quando Robert Rauschenberg ganhou o prêmio da Bienal de Veneza em 1964, os críticos de arte franceses acusaram a instituição de promover uma colonização cultural americana. ${ }^{14}$

Para o bem e para o mal, a conexão entre os mundos artísticos franceses e americanos estava sendo mais e mais promovida, e isso também era verdade em relação aos happenings e às performances. Em 1964, Jean-Jacques Lebel havia organizado o festival La Libre Expression, onde Carole Scheemann realizou pela primeira vez sua clássica Meat Joy. Um ano antes, em 1963, Jack Smith também havia feito seu vídeo Flaming Creatures com paus, bucetas e seios numa grande e violenta orgia. Os trabalhos de Vito Acconci eram conhecidos em Paris, pelo menos desde 1962, quando este expôs no Festival d'Automne.

Journiac absorvia estas influências e trabalhava a partir delas. A importância de objetos comuns para as práticas artísticas, algo primeiro articulado por Marcel Duchamp, mas também enfatizado nos procedimentos da Pop Art, tornou-se um traço importante de seus trabalhos da década de $1960 .{ }^{15}$ Seus óleos sobre tela foram aos poucos se transformando em imagens tridimensionais que colapsaram os limites entre pintura e escultura. Arquivo do sexo foi

\footnotetext{
14 Em uma entrevista dada à critica de arte Catherine Millet em 1973, lleana Sonnabend disse que "[n]o começo [da década de 1960], havia um chauvinismo europeu enorme, certamente compreensível. Eu adoraria Ihe mostrar as matérias da imprensa sobre a Bienal de Veneza de 1964, quando Rauschenberg ganhou o prêmio. Todos gritavam: que invenção bárbara! É a morte do humanismo! É imperialismo cultural! Era como se quiséssemos fazer guerra quando na verdade queríamos apenas informar" (SONNABEND e MILLET, 1973, p. 18). Mesmo François Pluchart, o maior promotor da arte corporal na França e antigo colaborador de Michel Journiac, era, no início dos anos 1960, contra os movimentos de vanguarda artística em defesa da tradição pictórica francesa da École de Paris. Apenas mais tarde nessa década, ele mudou sua posição e lutou pela difusão e estabelecimento da art corporel. Cf., por exemplo, PLUCHART, 2002. Para uma discussão sobre a relação ambígua entre a body art americana e a constituição da art corporel na França, cf. BÉGOC, 2010.

15 Em 1973, Journiac escreveu: “Marcel Duchamp já desafiava pelo objeto a estrutura cultural que permitia com que suportes de garrafas se transformassem em outra coisa sendo ainda o que eram, sem se transformar [...] em um objeto estético, embora a estética não tenha - suas regras tendo desaparecido - qualquer significação, senão aquela de valorização social. $O$ trabalho de pesquisa, mediado pelo objeto, almeja o fato sociológico ambíguo não apenas por sua negatividade, mas porque existimos apenas por ele que, ao mesmo tempo, nos nega a vida." (JOURNIAC, 2013, p. 114).
} 
Performances de gênero e gêneros em performance: reflexões sobre a arte e os corpos... Vitor Grunvald

um módulo em forma de caixa na qual Journiac propôs um paralelismo, uma conexão entre a boca/buceta pintada com cores de sangue-e-carne e aquilo que está dentro do zíper de um tecido, isto é, o próprio corpo.

\section{Corpo e roupa}

A dialética entre corpo e objeto à qual Journiac se refere é pictoricamente expressa em muitas de suas pinturas e instalações. Nesse contexto, as roupas ocupam um lugar proeminente. "As roupas", ele escreve, "são sua forma [a forma do corpo] no sentido em que são o meio, a coisa através da qual encontramos alguém independente de seus rostos ou membros, para além do cuidado e da forma, até a putrefação que apenas os ossos resistirão" (JOURNIAC, 2013, p. 114).

Ainda em 1969, Journiac usa roupas como signo de antigos expoentes da arte que, simbolicamente convertidos em tecido, eram também suscetíveis à lavagem. A Lavagem foi uma exposição na Galeria Daniel Templon na qual se viam roupas rígidas que haviam sido encharcadas em tinta branca acrílica e penduradas num varal. Abaixo do varal, estavam cestos cheios de "roupas dos inúteis rejeitados", como escreve Wilson (2000, p. 164), referindo-se aos artistas que constituíram o movimento da Figuração Narrativa no início da década de 1960, na França, opondo-se à Pop Art e ao Nouveau Réalisme.

O contexto político e social francês daquele momento não pode ser negligenciado. Maio de 1968 foi o momento de ebulição de um movimento mais amplo no qual a sexualidade foi pensada como intrinsecamente imbricada com as normas sociais e sua subversão. A popularização das possibilidades terminológicas abertas pela teoria psicanalítica e a ideia de que a sexualidade devia ser vista como centro da experiência humana estavam conectadas com o deslocamento das fronteiras entre o público e o privado. 
Performances de gênero e gêneros em performance: reflexões sobre a arte e os corpos... Vitor Grunvald

Em Eros e civilização, publicado em 1955 e traduzido para o francês na década seguinte, Marcuse observa que

no período contemporâneo, categorias psicológicas se tornam categorias políticas no sentido de que o privado e a psique individual se convertem em receptáculos solícitos de aspirações, sentimentos, impulsos e satisfações socialmente desejáveis e necessárias (MARCUSE, 1962[1955], p. viii).

Foi nessa conjuntura que "a questão da identidade - nacional, de classe, étnica, sexual, de gênero e individual - torna-se o quadro de referência dominante para artistas que reiteradamente construíam representações de si no período pós-1960" (JONES, 2006, p. 41). Na França, a sexualidade era claramente tomada como meio tanto de aprisionamento social quanto de sublimação não-repressiva, para usar a expressão do próprio Marcuse. ${ }^{16}$ Qualquer aspecto da vida social e política podia ser referido à sexualidade, e criticar os padrões morais que delineavam os limites aceitáveis da experiência sexual era também criticar a sociedade burguesa.

A ideia de homossexualidade estava, para Journiac, imediatamente relacionada com o cruzamento das fronteiras de gênero. O travestimento e a "troca de gênero", contudo, já estavam incipientes em 1969. Alguns meses antes de Piège pour un voyeur, "um complemento à obra Armadilha, O Substituto usou um dispositivo de parque de diversões com dois corpos nus fotografados e um espaço sem cabeça para que o público pudesse olhar através dele, apropriando-se de um corpo do sexo oposto caso assim desejasse" (WILSON, 2000, p. 164).

A "troca de sexo" proposta nesse trabalho foi levada a cabo numa série de performances e fotografias a partir de 1972. Esse foi o ano em que Journiac começou a se travestir. De fato, ele usou,

\footnotetext{
16 A noção de sublimação não-repressiva está relacionada a "impulsos sexuais [que], sem perder sua energia erótica, transcendem seu objeto imediato e erotizam relações normalmente não-eróticas ou anti-eróticas entre indivíduos, e entre eles e seu meio ambiente" (MARCUSE, 1962[1955], p. ix). Para uma crítica dos pressupostos que subjazem o modelo de liberação de Marcuse, cf. FOUCAULT, 1988[1976].
} 
Performances de gênero e gêneros em performance: reflexões sobre a arte e os corpos... Vitor Grunvald

abusou e subverteu aquilo que Amelia Jones chamou de "códigos indumentários da masculinidade artística". Ela argumenta que:

As roupas fazem do corpo do artista algo tanto visível (permitindo sua significação) quanto invisível (imbricando-o nos naturalizados e aparentemente transparentes códigos do gênio masculino). A mudança nas percepções de identidade artística e da masculinidade em geral podia ser alcançada com o contraste de códigos indumentários (JONES, 1995, p. 19).

No experimento inicial de travestimento, contudo, foi Gérard Castex e não Journiac que brincou com a troca de roupas. Armadilha para um travesti apresenta uma série de quatro fotografias nas quais vestir-se, despir-se e travestir-se transformavam um homem com um traje masculino num corpo nu e, então, em Greta Garbo ou Rita Hayworth e, finalmente, na última fotografia, a audiência podia ver o nome da artista feminina na qual Gerard havia se transformado, mas, ao invés da imagem da "estrela", aparecia Journiac refletido num espelho.

Tudo se passa como se diferentes combinações de corpo e roupa - sujeitos e objetos ou, para usar um jargão hoje bastante comum na antropologia, as articulações entre humanos e não-humanos (LATOUR, 1994[1991], 2005) - produzissem diferentes modos de estar-no-mundo. Journiac explicitamente argumenta que "as roupas são objetos feitos corpo" (JOURNIAC, 2013, p. 114). E se tomamos o corpo como algo constitucionalmente relacionado à maneira como percebemos os outros e somos percebidos no mundo, os corpos são também, em certo sentido, roupas, como, a partir de outro lugar, tão bem argumenta a literatura etnológica americanista. ${ }^{17}$

Em 1970, Deleuze, absorvido pelo mesmo contexto político-social de Journiac, publica um livro sobre Spinoza no qual reforça a ideia de que o que realmente importa é o que um corpo pode e

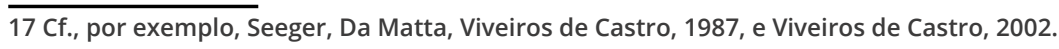


Performances de gênero e gêneros em performance: reflexões sobre a arte e os corpos... Vitor Grunvald

não o que um corpo é. Quão apropriada não é essa percepção para pensar as próprias estratégias do travestimento? ${ }^{18}$

Corpo de homem, corpo nu, corpo de uma estrela de cinema. Rita Hayworth, Greta Garbo, Arletty... todas símbolos de uma feminilidade que, segundo a lógica do que Guy Debord chamou em 1967 de "sociedade do espetáculo", são oferecidas ao olhar para serem admiradas e - por que não? - possuídas. Na década de 1970, ancorada em conceitos psicanalíticos aplicados à teoria do filme, Laura Mulvey (1989) tornou bastante popular a ideia de que o olhar é uma prerrogativa masculina - ideia, aliás, também defendida por John Berger (1999[1972]).

Inevitavelmente, minha memória histórico-artística me lembra que Cindy Sherman estava para começar, mais tarde nesta década, sua série de fotografias espectrais intitulada Untitled Film Stills. Nesta série, a artista aparece travestida de muitas outras pessoas, especialmente mulheres. A performance fotográfica é precisamente elaborada tendo como referências clichês do cinema hollywoodiano e da publicidade. Sabe-se que é a artista ali e que aquilo foi encenado. A artista não apresenta nenhuma intenção ilusionista e, lembrando o teatro de Brecht, não busca nunca esconder o palco. Os bastidores são inseparáveis de sua performance fotográfica e não algo exterior ou obliterado por ela.

24 horas na vida de uma mulher comum é uma série de fotografias produzidas por Journiac em 1974 - portanto, três anos antes de Sherman iniciar sua clássica série - que mostra o artista travestido de acordo com estereótipos veiculados por revistas como Marie Claire. Ele realiza tarefas tradicionalmente associadas ao mundo feminino e à vida privada.

O trabalho de Journiac coloca o corpo e a performance como lugar onde arte e política são escritas e reescritas e ele foi, de fato, um ativo participante nos debates de 1970 sobre os papéis de gênero e a homossexualidade. É importante lembrar que, alguns anos mais tarde, Foucault (1982[1978]) escreveria sua famosa in-

18 Cf. o livro de Deleuze Espinosa. Filosofia Prática (2002[1981]) publicado originalmente em 1970 e ampliado em 1981 pelo autor. 
Performances de gênero e gêneros em performance: reflexões sobre a arte e os corpos... Vitor Grunvald

trodução às memórias de Herculine Barbin. E Deleuze e Guattari (2004[1972]) já haviam publicado, no início desta década, sua feroz crítica à psicanálise, O Anti-Édipo. Travestimento, papéis de gênero, erotismo, sexualidade, família e psicanálise estavam todos entrelaçados e eram largamente discutidos entre ativistas, artistas e intelectuais na França.

Homenagem à Freud. Observação crítica de uma mitologia travesti é exemplar nesse sentido. É uma fotopeça serial que foi produzida também como pôster enviado por correio a algumas pessoas. Consistia de quatro fotografias separadas em pares. O primeiro par é composto pelo pai de Journiac e ele próprio travestido de seu pai. No segundo par, o mesmo procedimento, mas agora com a mãe. Todas as fotos possuem legenda. Nas de cima, lê-se: "Papai: Robert Journiac travestido em Robert Journiac"; "Filho: Michel Journiac travestido em Robert Journiac". Nas de baixo: "Mamãe: Renée Journiac travestida em Renée Journiac"; "Filho: Michel Journiac travestido em Renée Journiac". Esse trabalho é canônico para as reflexões que quero realizar aqui, mas antes de passar a ele, gostaria de remeter à questão da reversibilidade na performance de gênero colocada em curso décadas antes por aquele que Journiac tem como uma de suas influências explícitas.

\section{Rrose, Journiac e a reversão do travestimento}

Rrose Sélavy é o nome com o qual Duchamp assinou muitas de suas obras. Ela é também a persona fotografada pelas lentes de Man Ray numa série de retratos realizados em 1920-21. Para além da análise que deseja vê-la apenas como um exemplo artístico concreto da "síndrome Tootsie", Amelia Jones insiste que o eixo Marcel/Rrose é marcado por "uma ambivalência (ou, talvez, mais propriamente, uma mutivalência) no jogo de identidades de gênero e sexuais" (JONES, 1994, p. 151).

Num ensaio sobre performance de gênero na fotografia, Jennifer Blessing sugere que: 
Performances de gênero e gêneros em performance: reflexões sobre a arte e os corpos... Vitor Grunvald

Esse vai-e-vem é a pedra angular do trabalho de Duchamp que se desdobra pelo curso de sua vida. Após desenhar um bigode na Mona Lisa, transformando 'ela' em 'ele', em 1965, ele a barbeia criando um travestimento reverso. Da mesma forma, um manequim feminino é travestido com as roupas de Duchamp na Exposition Internationale du Surréalisme de 1938, revertendo o travestimento homem-para-mulher de Rrose (BLESSING, 1997, p. 23)

Sem o jogo de vai-e-vem, poderíamos considerar Rrose Sélavy como uma cópia - deformada, deslocada, mas ainda cópia - de um original, o "verdadeiro" Marcel Duchamp. Mas quando Rrose aparece travestida de Duchamp, a oposição entre cópia e original é complicada e já não se pode estabelecer quem é uma ou outro. De fato, nesse processo de reversão do travestimento, o problema da cópia e do original é deslocado e perde sua pertinência, já que Marcel e Rrose emergem como modelos de uma dissimilaridade fundamental, ambos são simulacra. Marcel é uma unidade; Marcel e Marcel travestido de Rrose Sélavy é dualidade; mas Marcel, Marcel travestido de Rrose Sélavy e Rrose Sélavy travestida de Marcel é o resto: três ou três milhões. ${ }^{19}$

Mas Homenagem à Freud leva o argumento adiante: o travestimento não é apenas uma operação que desloca um corpo original e supostamente natural em relação às normas e expectativas sociais de gênero. Mais do que isso, ele é o meio primordial através do qual todos os corpos e pessoas vem à vida e ganham significância. Journiac se traveste como seu pai ou mãe, mas mesmo estes estão, em última instância, travestidos de si mesmos. Não há um Eu original ou estado pronto para a vida, nenhum corpo emerge sem as performances que os engendram.

Se essas imagens são como índices da agência de Journiac que funciona, assim, como pessoa distribuída (GELL, 1998), e se podem ser vistas como documentos performativos usados pelo artista em

19 Em entrevista a Pierre Cabanne, Duchamp: "Pra mim a cifra três numa importância, não do ponto de vista esotérico, mas do ponto de vista da numeração: um é unidade, dois é duplo, dualidade, três é o resto. Desde que você chegou à palavra três, você terá três milhões e é a mesma coisa" (CABANNE, 1987[1967]: 79) 
Performances de gênero e gêneros em performance: reflexões sobre a arte e os corpos... Vitor Grunvald

sua atuação, como sugere Jones (1998), então, é certo que Journiac estava se situando politicamente num debate caro a seu tempo. Ele apostava que o cruzamento das fronteiras de gênero era uma ferramenta poderosa e eficaz de desafiar normas estabelecidas. Foucault, numa entrevista a Jean Le Bitoux em 1978, também articulava essas questões:

Historicamente, quando seolha ao queeram práticas homossexuais, como apareciam na superfície, é absolutamente correto que a referência à feminilidade tem sido muito importante, pelo menos certas formas de feminilidade. Esse é todo o problema do travestimento; ele não é estritamente ligado à homossexualidade, mas é, sem dúvida, parte dela. (FOUCAULT; LE BITOUX, 2011[1978], p. 11)

\section{Políticas do travestimento}

\section{5}

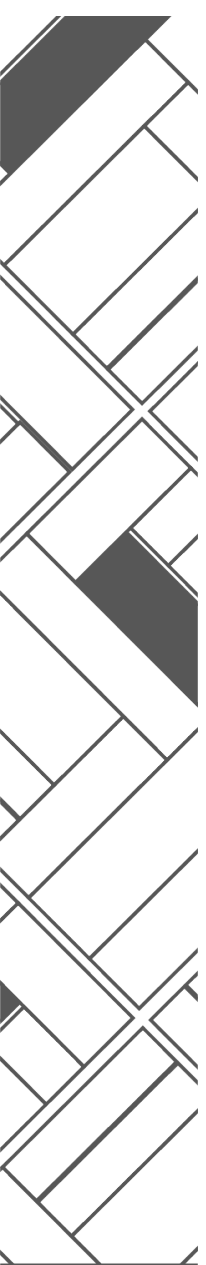

Talvez poucas insígnias sejam tão inteligíveis à nossa sensibilidade histórica quanto o triângulo rosa usado pelos nazistas para marcar os homossexuais. Esse reconhecimento é amplo em grande parte devido ao fato de que os então chamados movimentos de liberação homossexual reapropriaram o triângulo como símbolo de um orgulho gay, a despeito - ou, eu diria, por causa - dele ter sido criado como insígnia de vergonha. A força performativa das interpelações e práticas relacionadas à vergonha são fundamentais naquilo que Eve Sedgwick (1990) chama de "epistemologia do armário", contra as quais as reivindicações de orgulho emergiram. ${ }^{20}$

Em Ação de um corpo excluído, de 1983, Journiac literalmente se queima com um triângulo, relembrando-nos, uma década após iniciar seus travestimentos, que as questões relativas ao gênero e à sexualidade são e sempre serão questões relativas ao corpo. Ainda que alguns historiadores e críticos da arte tenham subli-

20 Para a inspiração teórica da discussão que realizo aqui sobre a vergonha e performatividade cf., adicionalmente, Sedgwick (2003). Para outras discussões sobre a vergonha que acionam, igualmente, uma perspectiva queer, cf. Halperin e Traub (2009). 
Performances de gênero e gêneros em performance: reflexões sobre a arte e os corpos... Vitor Grunvald

nhado estas questões, elas, em geral, aparecem como acessórias numa discussão mais ampla sobre o conjunto de significados relacionados às práticas corporais de Journiac de uma forma geral.

Quase que a totalidade dos textos que discutem seu trabalho nem mesmo falam sobre a importância de sua homossexualidade na arte que produziu - talvez, indicando o mesmo procedimento de "des-homossexualização" do qual Doyle, Flatley e Muñoz (1996) falam em relação a Andy Warhol. Meu argumento, por outro lado, busca mostrar que a ideia de travestimento desenvolvida no curso de suas experimentações com posições de gênero está no centro de sua agência artística e não pode ser pensada senão em conjunção com a ideia de (homo)sexualidade.

Na carta que escreveu ao seu pai, em junho de 1962, assumindo sua homossexualidade, Journiac claramente associa sua homossexualidade à um devir-mulher. Ele escreve: "Eu me tornei 'a menina', aquela da qual se fala no feminino, aquela que deve ser excluída das conversas entre homens" (JOURNIAC, 2013, p. 18). Sugiro que as performances de Journiac travestido são momentos em que ele deliberadamente (orgulhosamente) devém mulher mais do que é feito mulher pelas interpelações de vergonha realizadas por outros.

No seu livro sobre as políticas da performance, Peggy Phelan discute aquilo que chama "teatro do travestimento" e afirma que ele é "[t]alvez o melhor exemplo performativo da função fálica". Ela continua:

Um homem imita a imagem de uma mulher para confirmar que ela pertence a ele. No entanto, é necessário e desejável performar essa imagem externa e hiperbolicamente porque ele deseja se ver na possessão dela. Performar a imagem daquilo que ele não é o permite dramatizar a si mesmo como 'todos'. Mas a performance do travestimento não produz e não pode produzir 'a mulher'. Ao invés disso, ela reencena a performance da função fálica - marcando-a como ele. (PHELAN, 1993, p. 17) 
Performances de gênero e gêneros em performance: reflexões sobre a arte e os corpos... Vitor Grunvald

Com a percepção informada pelo meu trabalho de campo com pessoas transgêneras e por meus próprios devaneios de gênero, eu imagino que algo inteiramente diferente acontece nas performances de Journiac que analiso aqui. A leitura que faço delas sugere que, no jogo de subjetividades que realiza, é o homem que é levado pela mulher. Através destas performances, Journiac assegura que a pessoa "da qual se fala no feminino" (interpelação de vergonha) é também a pessoa que fala e se constrói performativamente no feminino (assertividade de orgulho).

É possível que Journiace outras performances do travestimento sejam apenas uma questão de pessoas (homens) que querem se ver na possessão de pessoas (mulheres) como sugerido por Phelan? Acredito que o mundo de uma travesti é mais constituído por ambiguidades e contradições do que proposições coerentes e estáveis. O que, é claro, não significa que a prática do travestimento não opera através de representações e ideias normativas; muito pelo contrário. ${ }^{21}$

Os argumentos de Peggy Phelan sobre as performances do travestimento são pouco palatáveis para mim. Carmelita Tropicana, a persona criada pelo travestimento da artista Alina Troyano, dificilmente os engoliria. Tropicana é, em algum sentido, invenção de Troyano, mas isso não significa necessariamente que é ela que está no comando. Como disse numa entrevista: "Carmelita tem chutzpah [audácia]. Alina, por outro lado, tem muitos medos" (ROMÁN e TROPICANA, 1995, p. 90). Estaria Alina performando Carmelita porque quer se ver na possessão dela? Seria essa lógica da dominação realmente aplicável? "Carmelita tem vida própria. Ela fala com um acento, pensa diferente de mim, mas somos colaboradoras maravilhosas!" (ROMÁN e TROPICANA, 1995, p. 88).

Foucault nos lembra que "a questão da feminilidade aparece [...] com grande ambiguidade no coração da homossexualidade." (FOUCAULT e LE BITOUX, 2011[1978]), p. 396). Ela permite à psi-

\footnotetext{
21 Pelúcio e Miskolci, num artigo sobre performatividade a partir de uma etnografia entre travestis, enfatizam que "ainda que desestabilizem o binarismo de sexo/gênero, as travestis, paradoxalmente, o reforçam em seus discursos e ações. Porém, é somente pelo paradoxo que elas podem expressar seu conflito com as normas de gênero vigentes. O paradoxo é a condição de sua ação (ou agência)" (PELÚCIO e MISKOLCI, 2007, p. 261).
} 
Performances de gênero e gêneros em performance: reflexões sobre a arte e os corpos... Vitor Grunvald

quiatria controlar e normalizar o corpo dos homossexuais. No entanto, mais recentemente, "ela permitiu que fosse levado a cabo um contra-ataque inverso". Ele pontua que:

Como resultado, emergiu a possibilidade estratégica de relações com os movimentos feministas. E o direito para os homossexuais de dizer, nossa preferência [gôut] por homens não é uma forma distinta de culto falocêntrico, mas uma certa maneira de colocar a questão da feminilidade para nós que somos homens. Para que possamos, nós também, colocar essa questão" (FOUCAULT e LE BITOUX, 2011[1978], p. 396).

Não estaria Journiac fazendo também essa reivindicação política? Não estaria ele colocando a questão da feminilidade para ele enquanto homem (gay)? Ao expor a construção normativa das concepções da mulher na mídia, não estaria ele colocando a questão da feminilidade mesmo para as mulheres? Mesmo "a mulher como entidade molar tem que devir-mulher", escreveram Deleuze e Guattari (2005[1980], p. 68) alguns anos depois.

\section{Subjetividades à deriva}

Para finalizar gostaria de retomar o tropo do vampiro com o qual comecei o texto e lembrar um outro aspecto presente em algumas versões de sua mitologia, qual seja, a ideia que os vampiros não têm sua imagem refletida no espelho. Eu tomo essa afirmação como se referindo não tanto ao vampiro, mas ao espelho. Se Leon Battista Alberti, autor do primeiro tratado de pintura ocidental, pôde reivindicar Narciso como o inventor da pintura é porque, segundo ele, "o espelho é e deve ser o critério de toda similaridade, de toda imitação" (BONAFOUX, 2003, p. 24).

Outra versão dessa mesma fábula é aquela que anuncia, não o reflexo fidedigno dos espelhos, mas a visão límpida e transparen- 
Performances de gênero e gêneros em performance: reflexões sobre a arte e os corpos... Vitor Grunvald

te através de janelas. Considerada quer como espelho quer como janela para o mundo, a arte estaria mergulhada num modelo de relacionalidade em que a semelhança é entronizada como princípio norteador.

Um modelo completamente diferente é oferecido pela Fresh Widow de Marcel Duchamp, por exemplo. Nesta janela, em vez do vidro translúcido como de costume, vemos couro preto: nenhuma visão passa através da janela dando acesso a uma realidade lá fora, nenhuma reflexão é oferecida para a subjetividade aqui dentro.

Sugiro que, se o vampiro não tem sua imagem refletida no espelho, não é por alguma falta psicanalítica - vampiros tem falo? -, mas porque o espelho, em seu mundo, tem outra natureza que o faz perder completamente a pertinência de espelhamento marcado pela semelhança. Talvez, para lembrar a imagem de Victor Turner (1987), transforme-se num espelho mágico que não devolve vida senão como uma espécie de função derivada da fantasia que estranha e brinca com o próprio mundo.

Para Journiac, o travestimento não é um processo específico e secundário que desloca um Eu original, mas, sim, o processo deliberadamente inespecífico pelo qual toda e qualquer subjetividade é criada e recriada. Mesmo seus pais estão travestidos deles mesmos.

Sua arte parece propor um princípio relacional, segundo o qual as posições de sujeitos nunca estão garantidas já que não há modelo original para estabilizá-las. Nem mesmo o humano. Tão cedo quanto 1974, com a peça Journiac travestido em Deus, esse argumento é colocado adiante. Não se trata apenas de cruzamentos e transmutações que podem ocorrer entre posições sexuais e de gênero, mas também entre outros tipos de seres, cortando transversalmente inclusive a fronteira entre o humano e o sagrado.

Journiac travestido em cadáver conduz à ideia de que a investigação em relação aos modos de existência não se trata apenas de aparências externas, mas igualmente de composições internas. Vampiro, composição de natural (homem) e sobrenatural (espécie de Deus); composição de vida e morte. Algo no meio. 
Performances de gênero e gêneros em performance: reflexões sobre a arte e os corpos... Vitor Grunvald

De fato, se tomarmos esses trabalhos em conjunção com uso que faz de roupas como próteses que modificam o corpo, chega-se a um modo de existência fractal. Por um lado, ele disseca o corpo, o abre, o invade e o subtrai em direção aos ossos. Por outro lado, ele o fermenta, o aumenta e o amplifica através das roupas. Interior e exterior não fazem mais sentido.

Trata-se inteiramente de modos de estar-no-mundo, sua intercambialidade e a impossibilidade de um sentido sólido e imutável tanto de coerência interna (subjetividade estabilizada como identidade) quanto de consistência externa (mundo estabilizado como realidade).

Acredito que a ênfase de Journiac está sempre no meio. O que não é mais um homem, mas ainda não uma mulher? O que não é mais humano, mas ainda não Deus? O que é isso que eu não sou mais, mas estou prestes a me tornar, sem nunca completar integralmente o processo tornar-me? As subjetividades estão sempre $\mathrm{f}(\mathrm{r}) \mathrm{iccionadas}$ - emprestando a feliz expressão de John Dawsey (2007) por contradições que são imanentes e internas.

Pensando sobre o que eu quero dizer por contradição interna, paradoxo e curto-circuito, lembrei-me de um episódio que ocorreu alguns meses antes de escrever a primeira versão deste artigo. Indianara Alves Siqueira, uma ativista transvestigenere ${ }^{22}$ brasileira, estava na rua com os outros membros do grupo numa de suas manifestações. Ela não estava usando qualquer peça de roupa na parte superior do corpo e, portanto, tinha os seios expostos. A polícia chegou e a prendeu por atentado ao pudor. Ela foi liberada algum tempo depois com um aviso de que teria que ir para um Tribunal de Justiça para explicar a ocorrência, ser julgada e receber a sentença.

Indianara começou a elaborar (e publicar) sua estratégia legal. Se as autoridades judiciais a condenassem por atentado ao pudor por não usar camisa em espaço público, estariam reconhecendo-a

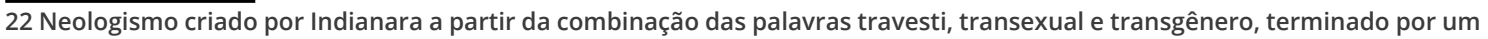
"e" que indica alternativa gênero-neutro em relação ao "o" ou "a" usualmente utilizados na língua portuguesa que marcam, de forma indelével, a necessidade obrigatória de masculino ou feminino ou de um masculino englobante.
} 
Performances de gênero e gêneros em performance: reflexões sobre a arte e os corpos... Vitor Grunvald

legalmente como mulher que, assim sendo, não teria o direito de mostrar os seios em público sem cometer a infração da qual havia sido acusada. Isso abriria um precedente legal para que todas as outras travestis fossem juridicamente reconhecidas como mulheres e não tivessem apenas seus "nomes sociais" nos documentos. Se, por outro lado, ela não fosse reconhecida como mulher, a justiça não poderia condená-la, uma vez que a um homem é permitido ter a parte superior do corpo completamente nua e exposta em público. Essa foi a armadilha de Indianara.

Naturalmente, Michel Journiac e Indianara Siqueira são separados por diferentes realidades nacionais e sociais, diferentes tempos e assim por diante. No entanto, pode-se dizer que vibram na mesma frequência na medida em que provocam tremores que desestabilizam o mundo social a partir de dentro. Para ambos, não é uma questão de criar novas convenções que seriam supostamente livres das restrições da coerção social. Declarações supostamente libertadoras sempre podem ser facilmente recapturadas pela lógica social dominante e convertidas, seja em desvios, seja em exceções à normalidade. E tudo segue como sempre seguiu.

De maneira diversa, eles colocam em curso um engajamento político baseado em incongruências internas. Executam estratégias em que "a partir das formas que se tem, do sujeito que se é, dos órgãos que se possui ou das funções que se preenche" (DELEUZE e GUATTARI, 2005[1980], p. 64), o que importa é implodir e minar o estado atual de coisas a partir de suas inconsistências. Não para a construção de uma outra série de convenções, mas para dar ao mundo movimentos, ficar à deriva no mar aberto. ${ }^{23}$

As performances de Jouniac travestido, ao mesmo tempo estéticas e políticas, usaram e abusaram de estereótipos de performances sociais que operam com as convenções mais essencializadas sobre o que uma mulher é e faz, transformando-as não em

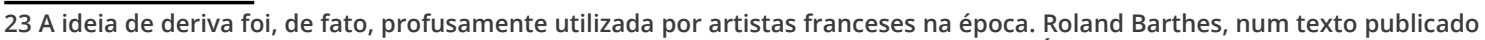
na revista Art Press, em 1973, explica que: “[A] deriva é uma busca ativa de dissociação. É a consistência agressiva das línguas que visa ser dissociada. Deriva é uma prática de inconsistência. Não há forma de escapar da guerra de línguas (o que queremos, mas não podemos); simplesmente isso: apontar para um outro lugar que está dentro (essa é a mesma imagem da palha flutuante), usar milhares de práticas de escrita para frustrar as aquisições, os acessos fáceis, as garantias, todo esse querer-alcançar que está à espreita na organização da própria linguagem" (BARTHES, 1973, p. 9).
} 
Performances de gênero e gêneros em performance: reflexões sobre a arte e os corpos... Vitor Grunvald

espelhos do real, mas numa poderosa ferramenta com a qual ele pôde criticar e quebrar a coerência e a consistência das próprias normas de gênero vigentes, expondo aquilo que Bruce Nauman, na obra Window or wall sign, chama de "verdades místicas".

\section{Bibliografia}

BARTHES, Roland, Supplément. Art Press, 4: 9, 1973.

BARTHES, Roland. Pour une sociologie du vêtement. Annales. Histoire, Sciences Sociales, n. 2, p. 404-407, 1960.

BARTHES, Roland. Histoire et sociologie du vêtement: quelques observations méthodologiques. Annales. Histoire, Sciences Sociales, v. 12, n. 3, p. 430-441, 1957.

BARTHES, Roland. The language of fashion. Oxford, New York: Berg, 2005[1998].

BARTHES, Roland. Sistema da moda. São Paulo: Martins Fontes, 2009[1967].

BÉGOC, Janig. Entre émulation et instrumentalisation: la place du Body Art américain dans la constitution de l'art corporel en France. In: BÉGOC, Janig; BOULOUCH, Nathalie; ZABUNYAN, Elvan (Orgs.). La performance: entre archives et pratiques contemporaines. Rennes: Presses Universitaires de Rennes, 2010.

BERGER, John. Modos de ver. Rio de Janeiro: Rocco, 1999[1972].

BLESSING, Jennifer. Rrose is a Rrose is a Rrose. In: BLESSING, Jennifer (Org.). Rrose is a Rrose is a Rrose. New York, Guggenheim Museum, 1997.

BONAFOUX, Pascal. L `autoportrait. Seánce Du mercredi 12 février 2003. Académie de Beaux-Arts, 2003. Disponível em: http:// www.academie-des-beaux-arts.fr/actualites/travaux/Bonafoux. pdf. Acesso em: 15 jul. 2011. 
Performances de gênero e gêneros em performance: reflexões sobre a arte e os corpos... Vitor Grunvald

BOURCIER, Marie-Hélène/Sam. Entrevista com Marie-Hélène/Sam Bourcier. Revista Cult, ano 18, n. 205, setembro, p. 11-15, 2015.

BUTLER, Judith. El género em disputa. México: Paidós, 2001[1990].

CABANNE, Pierre. Marcel Duchamp: engenheiro do tempo perdido. São Paulo, Perspectiva, 1987[1967].

DAWSEY, John. Sismologia da performance: ritual, drama e play na teoria antropológica. Revista de Antropologia, v. 50, n. 2, p. 527-570, 2007.

DE BEAUVOIR, Simone. O segundo sexo. Fatos e Mitos. São Paulo: Difusão Europeia do Livro, 1970[1949].

DELEUZE, Gilles; GUATTARI, Félix. O Anti-Édipo: capitalismo e esquizofrenia. Lisboa, Assirio e Alvim, 2004[1972].

DELEUZE, Gilles; GUATTARI, Félix. Mil platôs: capitalismo e esquizofrenia. v. 4. Rio de Janeiro: Editora 34, 2005[1980].

DELEUZE, Gilles. Espinosa: filosofia prática. São Paulo: Escuta, 2002[1981].

DOYLE, Jennifer; FLATLEY, Jonathan; MUÑOZ, José Esteban.

Introduction. In: DOYLE, Jennifer; FLATLEY, Jonathan; MUÑOZ, José Esteban (Orgs.). Pop Out. Queer Warhol. Durham, London: Duke University Press, 1996.

FOUCAULT, Michel. Herculine Barbin: o diário de um hermafrodita. Rio de Janeiro, F. Alves, 1982[1978].

FOUCAULT, Michel; LE BITOUX, Jean. The Gay Science. Critical Inquiry, 37 (3), 2011[1978]. Disponível em: http://criticalinquiry. uchicago.edu/uploads/pdf/Foucault,_The_Gay_Science.pdf. Acesso em: 26 jan. 2014.

FOUCAULT, Michel. A verdadeiro sexo. In: BARBIN, Herculine.

Herculine Barbin: o diário de um hermafrodita. Rio de Janeiro: F. Alves, 1982[1978]. 
Performances de gênero e gêneros em performance: reflexões sobre a arte e os corpos... Vitor Grunvald

FRANÇA, Isadora Lins. Consumindo lugares, consumindo nos lugares: homossexualidade, consumo e subjetividades na cidade de São Paulo. Rio de Janeiro: EDUERJ, 2012.

GELL, Alfred. Wrapping in images. Tattooing in Polynesia. Oxford: Claredon Press, 1993.

GELL, Alfred. Art and agency. An anthropological theory. Oxford, Claredon Press, 1998.

GOW, Peter. Clothing as acculturation in Peruvian Amazonia. In: EWART, Elizabeth; O'HANLON, Michael (Orgs.). Body arts and modernity. Wantage: Sean Kingston Publising, 2007.

GREGOR, Thomas; TUZIN, Donald. Comparing Gender in Amazonia and Melanesia. In: GREGOR, Thomas; TUZIN, Donald (Orgs.). Gender in Amazonia and Melanesia. Berkeley, Los Angeles, London: University of California Press, 2001.

GRUNVALD, Vitor. Alter-retrato, fotografia e travestimento ou sobre o paradigma fotográfico de Rrose Sélavy. In: CAIUBY NOVAES, Sylvia. (Org.). Entre arte e ciência: a fotografia na antropologia. São Paulo: Edusp, 2015.

GRUNVALD, Vitor. Butler, a abjeção e seu esgotamento. In: DÍAZBENÍTEZ, María Elvira; FíGARI, Carlos (Orgs.). Prazeres dissidentes. Rio de Janeiro: Garamond, 2009.

GRUNVALD, Vitor. Teseu e o touro: algumas sugestões feministas para uma crítica da razão. Dissertação (Mestrado em Antropologia Social) - Museu Nacional, UFRJ, Rio de Janeiro, 2009.

GRUNVALD, Vitor. Existências, insistências e travessias: sobre algumas políticas e poéticas de travestimento. Tese (Doutorado em Antropologia Social) - Universidade de São Paulo, São Paulo, 2016.

HALBERSTAM, Jack. Skin Shows: Gothic Horror and the Technology of Monsters. Durham: Duke University Press, 1995. 
Performances de gênero e gêneros em performance: reflexões sobre a arte e os corpos... Vitor Grunvald

HALPERIN, David; TRAUB, Valerie (Orgs.). Gay Shame. Chicago: Chicago University Press, 2009.

JONES, Amelia. Postmodernism and the En-gendering of

Marcel Duchamp. Cambridge, Cambridge University Press, 1994.

JONES, Amelia. Body Art/performing the subject. Minneapolis, London, University of Minnesota Press, 1998.

JONES, Amelia. Self/Image. Technology, Representation and the Contemporary Subject. London, New York: Routledge, 2006.

JOURNIAC, Michel. Écrits. Paris: Beaux-Arts de Paris, 2013.

LATOUR, Bruno. Jamais fomos modernos. Rio de Janeiro, Ed. 34, 1994[1991].

LATOUR, Bruno. Reassembling the social. New York, Oxford, Oxford University Press, 2005.

LEITE JR., Jorge. Nossos corpos também mudam. A invenção das categorias "travesti" e "transexual" no discurso cientifico. São Paulo: Annablume, 2011.

MARCUSE, Herbert. Eros and Civilization. New York: Vintage Books, 1962[1955].

MCCLINTOCK, Anne. Couro Imperial. Raça, gênero e sexualidade no embate colonial. Campinas: Editora da Unicamp, 2010[1995].

MISKOLCI, Richard; SIMÕES, Júlio. Apresentação. Dossiê Sexualidades Disparatadas. Cadernos Pagu, v. 28, p. 9-18, 2007. MULVEY, Laura. Visual and other pleasures. New York: Palgrave Macmillan, 1989.

PELÚCIO, Larissa; MISKOLCl, Richard. Fora do sujeito e fora do lugar: Reflexões sobre performatividade a partir de uma etnografia entre travestis. Revista Gênero, Niterói, v. 7, n. 2, p. 255-267, 2007.

PHELAN, Peggy. Unmarked. The Politics of Performance. New York: Routledge, 1993. 
Performances de gênero e gêneros em performance: reflexões sobre a arte e os corpos... Vitor Grunvald

PLUCHART, François. L'art: un acte de participation au monde. Nîmes: Éditions Jacqueline Chambon, 2002.

ROMÁN, David; TROPICANA, Carmelita. Carmelita Tropicana Unplugged: an interview. TDR, v. 39, n. 3, p. 83-93, 1995.

ROUILLÉ, André. A fotografia. Entre documento e arte contemporânea. São Paulo: Senac, 2009[2005]

RUBIN, Arnold (Org.). Marks of Civilization: Artistic Transformations of the Human Body. Museum of Cultural History. Los Angeles: University of California, 1988.

SAHLINS, Marshall. Cultura e razão prática. Rio de Janeiro: Jorge Zahar, 2003[1976].

SCHECHNER, Richard. Between theater and anthropology. Philadelphia: University of Pennsylvania Press, 1985.

SEDGWICK, Eve. Epistemology of the Closet. Berkeley, LoS Angeles, London: University of California Press, 1990.

SEDGWICK, Eve. Touching Feeling. Affect, Pedagogy, Performativity. Durham, London: Duke University Press, 2003.

SEEGER, Anthony; DA MATTA, Roberto; VIVEIROS DE CASTRO, Eduardo. A construção da pessoa nas sociedades indígenas brasileiras. In: OLIVEIRA FILHO, João Pacheco et al. (Orgs.). Sociedades indígenas \& Indigenismo no Brasil. Rio de Janeiro: Marco Zero/ UFRJ, 1987.

SONNABEND, Ileana; MILLET, Catherine. Aspects de l'art actuel. Art Press, v. 7, p. 18-19, 1973.

STRATHERN, Marilyn. Same-sex and Cross-sex Relations: Some Internal Comparisons. In: GREGOR, Thomas; TUZIN, Donald (Orgs.). Gender in Amazonia and Melanesia. Berkeley, Los Angeles, Londres: University of California Press, 2001.

THOMAS, Nicholas. Foreword. In: GELL, Alfred. Art and agency. An anthropological theory. Oxford, Claredon Press, 1998. 
Performances de gênero e gêneros em performance: reflexões sobre a arte e os corpos... Vitor Grunvald

TURNER, Victor. The anthropology of performance. New York: PAJ Publications, 1987.

VIVEIROS DE CASTRO, Eduardo. A inconstância da alma selvagem e outros ensaios de antropologia. São Paulo: Cosac \& Naify, 2002.

WILSON, Sarah. Monsieur Venus. Michel Journiac and Love. In: ARSCOTT, Caroline; SCOTT, Katie (Orgs.). Manifestations of Venus. Art and sexuality. Manchester: Manchester University Press, 2000. 